\title{
Legal aspects of environmental safety in the field of medical waste management in the context of the pandemic
}

\author{
Nadezhda A. Alekseeva $\square$ \\ Russian State University of Justice, \\ Moscow, Russian Federation \\ \knadege@yandex.ru
}

\begin{abstract}
Medical waste management has always been relevant from a practical point of view, but as a result of the pandemic declared in 2020, this topic has multiplied, leading to significant changes in the legal regulation of medical waste. The realization that re-contamination from medical covid-waste is possible led to the obligation to install disinfectants in medical and pharmacological organizations. The division of medical waste into classes predetermined the assignment of medical covid-waste to class " $\mathrm{B}$ ", and after disinfection - to "A"-class, that are possible to transport and dispose after disinfection. However, there is a huge amount of covid-waste outside medical and pharmacological organizations, which is, clearly, are not medical. When mixed with solid household waste and garbage that does not require a transport licence, it increases the likelihood of re-infection of those who handle such waste. The object of the work is to explore these topics and to raise the issue of separation of the accumulation and disposal of non-medical covid-waste in legal regulation, as well as the ways to implement them. Related to this is the issue of environmental pollution in the context of the pandemic, because non-medical covidwaste has increased the amount of plastic that pollutes the environment.
\end{abstract}

Key words: Medical waste, waste classes, medical waste management, non-medical waste, covidwaste, covid-waste disposal, covid-waste in the environment

Conflict of interest. The author declared no conflicts of interest.

Article received 31st May 2021

Article accepted 15th July 2021

\section{For citation:}

Alekseeva, N.A. (2021) Legal aspects of environmental safety in the field of medical waste management in the context of the pandemic. RUDN Journal of Law. 25 (3), 586-601. DOI: $10.22363 / 2313-2337-2021-25-3-586-601$

(C) Alekseeva N.A., 2021

This work is licensed under a Creative Commons Attribution 4.0 International License https://creativecommons.org/licenses/by/4.0 


\title{
Правовые аспекты экологической безопасности в области обращения с медицинскими отходами в условиях пандемии
}

\author{
Н.А. Алексеева \\ Российский государственный университет правосудия, \\ 2. Москва, Российская Федерация \\ $\triangle$ knadege@yandex.ru
}

\begin{abstract}
Аннотация. Вопросы утилизации медицинских отходов являлись всегда актуальными с практической точки зрения, но в результате пандемии, объявленной в 2020 г., актуальность темы возросла в разы, что привело к значительным изменениям правового регулирования в области медицинских отходов. Понимание того, что от медицинских ковид-отходов возможно повторное заражение, привело к обязанности по внедрению в медицинские и фармакологические учреждения дезинфицирующих установок. Деление медицинских отходов на классы предопределило отнесение ковид-отходов к классу «В», а после дезинфекции - к «А» - классу, возможному к перевозке и утилизации после дезинфекции. Вместе с тем существует огромное количество ковид-отходов, образующихся вне медицинских и фармакологических учреждений, явно не являющиеся медицинскими. Смешиваясь с твердыми бытовыми отходами, для осуществления услуг, по транспортировке которых нет необходимости получения лицензии, они увеличивают вероятность повторного инфицирования лиц, работающих с такими отходами. В работе поставлена задача исследовать указанные темы и разрешить такой вопрос, как необходимость отдельного правового регулирования накопления и утилизации немедицинских ковид-отходов, а также реальные пути их осуществления. Попутно затронуты вопросы загрязнения окружающей среды в связи с пандемией, поскольку немедицинские ковид-отходы повысили количество пластика, загрязняющего окружающую среду.

Ключевые слова. Медицинские отходы, классы отходов, утилизация медицинских отходов, немедицинские отходы, ковид-отходы, утилизация ковид-отходов, ковид-отходы в окружающей среде
\end{abstract}

Конфликт интересов. Автор заявляет об отсутствии конфликта интересов.

Дата поступления в редакиию: 31 мая 20212.

Дата принятия к печати: 15 января 2021 г.

\section{Для цитирования:}

Alekseeva N.A. Legal aspects of environmental safety in the field of medical waste management in the context of the pandemic // RUDN Journal of Law. 2021. T. 25. № 3. C. 586-601. DOI: $10.22363 / 2313-2337-2021-25-3-586-601$

\section{Introduction}

The first official COVID-19 outbreak in Wuhan, China, was reported by the World Health Organization $^{1}$ (here and further - WHO) on 31 December 2019. By January 3, 2020, 44 cases of the new virus had already been identified. On January 22,

\footnotetext{
${ }^{1}$ Wuhan Municipal Health Commission briefing on the pneumonia epidemic situation. 31 December 2019 (in Mandarin). Available at: http://wjw.wuhan.gov.cn/front/web/showDetail/2019123108989 [Accessed 13rd April 2021].
} 
2020, Wuhan Province was closed to quarantine. On 30 January 2020, the World Health Organization recognized an epidemic that was caused by a "public health emergency of international significance" in connection with the spread of the virus. On March 30, 2020, Russia closed its borders. Both this information and evolution of the situation are well known ${ }^{2}$. A new coronavirus infection caused by SARS-CoV-2 is included in the list of diseases that pose danger to others by the Decree of the Government of the Russian Federation ${ }^{3}$. Today, the number of daily illnesses worldwide, while declining, is significant. Despite the negative picture of coronavirus, scientists have noted some trends in the impact of quarantine measures on the environment: on the one hand, there are positive trends in the reduction of emissions and discharges, This is due to a decline in economic and industrial activity in 2020, and to an increase in the number of wastes associated with coronavirus infection.

There are some studies that address the legal management of medical waste, but they do not give the comprehensive picture of the issue. There are just a few works devoted to covid-waste, however, the topic demands additional coverage especially on non-medical covid-waste.

Comparative analysis and synthesis are basic to identify legislative regulation and to determine whether it can be applied to issues that are not directly related to medical waste.

The purpose of the study is to investigate legal regulation of covid-waste and to identify the need for its licensing. Environmental safety issues are related to the nonmedical treatment of covid-waste generated outside medical and pharmacological institutions; potentially, they are prone to subsequent contamination due to mixing with solid household waste and garbage so the environmental protection issues related to the release of personal protective equipment into solid household waste are highly relative.

The purpose can be reached through studying the issues concerning medical waste and licensing selected activities related to it. Also, in the focus is the question of whether covid-waste is classified as medical and is it subject to legal regulation when mixing with solid household waste.

\section{Legal Regulation of Medical Waste}

The topic of medical waste management is relevant in the field of legal regulation, as it includes collection, storage, transport, treatment, recycling, decontamination and disposal, what legislation calls "handling". Researchers in this field are A.Yu. Orlov, M.V. Ponomarev, O.V. Mironenko, I.V. Mokrousov and V.V. Perelygin, N.A. Sklyarova, S.G. Paramonov, T.A. Pyatizbyantsev (Orlov, 2010:170; Ponomarev, 2019:352 - 358; Ponomarev \& Mironenko, 2004:431; Mokrousov, 2006:177; Perelygin, Sklyarova, Paramonov \& Pyatizbyantsev,

\footnotetext{
${ }^{2}$ Statement on the second meeting of the International Health Regulations (2005) Emergency Committee regarding the outbreak of novel coronavirus (2019-nCoV). Available at: https://www.who.int/newsroom/detail/30-01-2020-statement-on-the-second-meetingof-the-international-health-regulations-(2005)emergency-committee-regarding-the-outbreak-of-novel-coronavirus-(2019-ncov) [Accessed 3rd March 2021]. ${ }^{3}$ Decree of the Government of the Russian Federation No. 66 of 31.01.2020 On Amendments to the List of Diseases that Pose Danger to Others". Consultant Plus Legal System.
} 
2019:78-83; Cherevchina, 2012; Zudinova, 2017; Polyaninov \& Cherevchina, 2011). Thus, the topic under consideration is more or less sufficiently explored. However, in the context of the present epidemiological situation, when appearance of a new coronavirus infection 2019-nCoV or COVID-19 (hereinafter - a corona virus) ${ }^{4}$ has been confirmed and $\mathrm{WHO}^{5}$ has declared the pandemic ${ }^{6}$, when the numbers of those infected and those who died are extremely high, new aspects came to the forefront and need to be investigated and clarified.

It seems that medical waste management activities should fully comply with the fundamental principles of health care in Russia, including the "priority of the patient's interests in providing medical care" envisaged by the Federal Law On Fundamentals of Health Protection of Citizens ${ }^{6}$. After adoption of this law, the concept of medical waste has been expanded to include medical, pharmaceutical and biological waste. However, the question of whether to include all types of waste generated by medical or pharmaceutical organizations in the course of their activities into the category of medical waste is not yet resolved. Unresolved is also the question whether they are subject to provisions of Art. 49 Par. 1 of the Law or they are subject to medical waste (due to the provisions of the Letter of the Rosnatural Survey A-03-04-36/6554 of 22.04.20157, which bears recommendatory character). These issues complicate understanding of the matter in spite of the position of the Supreme Court of the Russian Federation ${ }^{8}$.

By virtue of Art. 2 Par. 2 of the Federal Law Federal Law On Production and Consumption Waste $^{9}$ relations in the field of handling medical wastes are regulated by the legislation of the Russian Federation. However, one of the current problems in this area is that there is no special law regulating the disposal of medical waste in the Russian Federation, and it is necessary to refer to general legislation on waste management (Art. 2, Par. 1). The specific legal regulation has been abandoned in practice with various by-laws regulations.

Modern Russian legislation contains the concept of medical waste. According to Art. 49 Par. 1 Law 323 medical wastes are "all types of anatomical, biochemical, microbiological and physiological waste, generated in the course of medical and pharmaceutical activities concerning production of medicines and medical products, use of infectious pathogens and genetically engineered organisms for medical purposes, as well as production and storage of biomedical cells products". Although covid-waste is clearly a source of infectious disease pathogens it is not covered by law as medical waste (as activities exempting from medical waste management, according to this article).

\footnotetext{
${ }^{4}$ Coronavirus. Chronicle of distribution. Available at: https://rg.ru/2020/03/03/koronavirus-hronikarasprostraneniia.html [Accessed 15th April 2021].

${ }^{5}$ TASS Russian news agency. Available at: https://tass.ru/info/7952651 [Accessed 3rd March 2021].

${ }^{6} \mathrm{WHO}$ declares a pandemic of the new coronavirus. Available at: https://www.bbc.com/russian/news51842591 [Accessed 3rd March 2021].

${ }^{6}$ Art. 4 of the Federal Law No. 323 of November 21, 2011 On Fundamentals of Health Protection of Citizens.

Consultant Plus Legal System.

${ }^{7}$ Letter of Rosprirodnadzor (the Federal Service for Supervision of Natural Resources Management) No. AA-03-04-36/6554 dated 22.04.2015 On Clarifications. Consultant Plus Legal System.

${ }^{8}$ Determination of the Supreme Court of the Russian Federation No. 306-KG 16-3171 of 27.04.2016 in case No. A55-12937/2015. Consultant Plus Legal System.

${ }^{9}$ Federal Law No. 89 of June 24, 1998 On Production and Consumption Waste. Consultant Plus Legal System.
} 
However, on the basis of the legal status of all wastes and in the absence of specific legislation on the issue of medical wastes, they are subject to civil law and property rights. But this does not correspond to the concept of a public danger of medical waste (Ponomarev \& Tsomartova, 2019:145-158). Taking into consideration the possibility of harm to human health and the environment (Chartier, Emmanuel \& Pieper (eds.), 2014), the status of medical waste is subject to clarification. Moreover, there is a need to review the legislative approach to transportation and disposal of medical waste by defining contract as a service related to a non-material good belonging to the sphere of ownership, and connect it with a high-risk medical waste (especially in its management (Pogodina \& Baranova, 2018:33-37.).

Medical waste is differentiated in accordance with Art. 49 par. 2. of the mentioned Law ${ }^{10}$ into epidemiological, toxicological and radiological hazards; their adverse impact on the environment rests on the criteria established by the Decree of the Government of the Russian Federation ${ }^{11}$ and falls into the following classes: epidemiologically safe waste - class " $A$ " is similar in composition to solid household waste; epidemiologically hazardous waste — class "B"; extremely epidemiologically dangerous waste - class "C"; toxicological hazardous waste is similar in composition to industrial waste - class " $D$ "; and radioactive waste — class " $E$ ".

The disposal of the waste in question is regulated by the Decision of the Chief Medical Officer of the Russian Federation ${ }^{12}$; in accordance with paragraph 1.3 its regulation is extended to legal persons and individuals and to all activities concerning the medical waste management. Thus, the Decree regulates both the activities of medical institutions and the partners to such institutions that have concluded contracts for the disposal of medical waste (in this respect the reference to citizens is at least odd). According to the Decree of the Government of the Russian Federation, waste management activities are divided into regulated phases, subject to mandatory medical examination and vaccination.

\section{Medical covid-waste}

Due to the current epidemiological situation in the Russian Federation and the lack of appropriate regulation, the Ministry of Health of the Russian Federation adopted the following clarifications ${ }^{13}$ for a rapid response: "On the procedure for handling medical waste in connection with the spread of coronavirus infection, the Ministry of Health of Russia has transferred the resulting COVID-19 waste to medical waste class "C", extremely dangerous. Before adopting the explanation, these wastes could be

\footnotetext{
${ }^{10}$ Federal Law No. 323 of 21.11.2011 On the Fundamentals of Health Protection of Citizens in the Russian Federation. Consultant Plus Legal System.

${ }^{11}$ Decree of the Government of the Russian Federation No. 681 of 04.07.2012 On Approval of Criteria for the Division of Medical Waste into Classes According to the Degree of their Epidemiological, Toxicological, Radiation Hazard, as Well as Negative Impact on the Environment. Consultant Plus Legal System.

${ }^{12}$ Decision of the Chief Medical Officer of the Russian Federation No. 163 of December 9, 2010 On Approval of Health Standards and Regulations 2.1.7.2790-10 Sanitary and Epidemiological Requirements for Treatment of Medical Waste. Consultant Plus Legal System.

${ }^{13}$ The Ministry of Health of the Russian Federation On the Procedure for Handling Medical Waste in Connection with the Spread of Coronavirus Infection. Available at: https://www.rosminzdrav.ru [Accessed 3rd March 2021].
} 
attributed by the persons responsible for their disposal to "B"-class waste and even to "A"-class waste with appropriate recycling procedure".

Studies of the time of SARS-CoV-2 conservation on contaminated surfaces have not given an accurate answer about the time of possible infection. In fact, the information is rather confusing: "SARS-CoV-2 conservation in the air under favourable conditions lasts three hours, on plastic surfaces - up to three days; it takes 6-7 days to completely destroy the virions on glass; on metal surfaces the activity of virions lasts two days; RNA is destroyed after six days on paper and on money - after four - five hours ${ }^{14}$. Considering personal protective equipment, virus time conservation on rubber medical gloves is from 8 to 20 hours". The contact with a possible carrier surface also involves a protective mask, where the virus can be active for up to a week ${ }^{15}$.

Thus, the time factor, as well as the forms of propagation and resulting consequences, give all reasons to classify it into the "C"-class. However, the studies on possible mutations of the virus ${ }^{16}$ raise the issue of classifying the covid-waste yet to another level.

Due to the epidemiological situation, the Ministry of Health of the Russian Federation explained the sanitary and epidemiological requirements for class " $\mathrm{C}$ " medical waste that generates as a result of medical treatment of coronavirus infection (COVID-19) (sanitary norms and rules 2.1.3684-21, instead of 2.1.7.2790-10) ${ }^{17}$. They specify the manner of collection, methods and techniques of decontamination, temporary storage and transportation of wastes of the appropriate class.

According to the Decision of the Chief State Sanitary Physician of the Russian Federation of May, 22, 2020 On the Approval of Sanitary and Epidemiological Rules 3.1.3597-20 "Prevention of new coronavirus infection (COVID-19)", coronavirus infection (COVID-19) is new, relates to acute respiratory disease caused by the new coronavirus (SARS-CoV-2), assigned to group II pathogenicity. The tests designed for COVID-19, as well as other wastes after medical manipulation with coronavirus infection (such as masks and gloves) also refer to medical waste class " $\mathrm{C}$ "; for example, COVID testing uses a sample of biological fluid from patient's nose or sputum from patient's respiratory tract, as well as laboratory reagents. Other staff also have a good chance of contacting virus particles; all these are regulated by mentioned

\footnotetext{
${ }^{14}$ COVID-19: Challenge the Innovation Community. Available at: https://sk.ru/news/covid19-vyzovinnovacionnomu-soobschestvu/ [Accessed 3rd March 2021].

${ }^{15}$ New Coronavirus Stable for Hours on Surfaces. Available at: https://www.niaid.nih.gov/news-events/newcoronavirus-stable-hours-surfaces [Accessed 3rd March 2021].

${ }^{16}$ Virologist assesses the danger of coronavirus mutations. Available at: https://rg.ru/2021/01/16/virusologocenil-opasnost-mutacij-koronavirusa.html [Accessed 3rd March 2021]; Rospotrebnadzor discovered almost 1.5 thousand coronavirus mutations in Russia. Available at: https://rg.ru/2021/01/15/rospotrebnadzorobnaruzhil-pochti-15-tysiachi-mutacij-koronavirusa-v-rossii.html [Accessed 3rd March 2021].

${ }^{17}$ Decision of the Chief State Sanitary Physician of the Russian Federation No. 3 of 28.01.2021 On Approval of Sanitary Rules and Norms of SanPiN 2.1.3684-21 Sanitary and Epidemiological Requirements for Maintenance of Urban and Rural Settlements, Water Bodies, Drinking Water and Drinking Water Supply, Atmospheric Air, Soils, Residential Premises, Operation of Industrial and Public Premises, Organization and Conduct of Sanitary and Anti-epidemic (Preventive) Measures (Sanitary Rules and Regulations 2.1.368421») // Available at: http://pravo.gov.ru. [Accessed 3rd March 2021].
} 
SanPiN. Medical waste disposal after laboratory tests is subject to special requirements if coronavirus is suspected ${ }^{19}$.

The legal regulation of medical waste class " $\mathrm{B}$ " is also available in the adopted Temporary Methodological Recommendations "Prevention, Diagnosis and Treatment of a New Coronavirus Infection (COVID-19)"18. According to it the wastes generated in cow barns and being extremely epidemiologically dangerous, are decontaminated (disinfected) or rendered harmless by thermal, microwave, radiation or other physical methods. Developed in 2021 Temporary Methodological Recommendations "Prophylaxis, Diagnosis and Treatment of New Coronavirus Infection (COVID-19)" envisage similar measures considering the specific mutation of the virus. However, recommendations to medical organizations on installing equipment to apply such techniques ${ }^{19}$ do not contain any binding rules or penalties for absence of such policy at the time of the present study. After decontamination, covid-waste can be accumulated, temporarily stored, transported, destroyed and buried together with " $A$ "-class waste. Therefore, it is not necessary to obtain a license for such activity. However, in the paragraphs below we will consider the cases of covid-waste from non-medical institutions which leaves the question of whether this type of activity should be licensed open.

In addition to legal regulations, there is a number of medical books, describing methods of disinfection (Makagonov, 2020). For example, with the support of Chinese scientists G.A. Makagonov has published Step-by-step Guide on Prevention and Treatment of a New Coronavirus Infection COVID-19, which is a lecture for doctors describing regulation of medical waste disposal. The issue is also addressed in published handbooks, such as the Environmental Handbook, which explains the obstacles to a modern, safe, high-technology waste management system.

Several disinfection technologies are based on WHO recommendations ${ }^{20}$; in accordance with them, disinfected medical waste can generally be disposed of together with household waste and rubbish at a landfill or discharged in liquid form into a sewer.

Let us look through the environmental issues related to the pandemic. The purity of ambient air during the lock-down period became better ${ }^{21}$. According to the Finnish Energy and Clean Air Research Centre Carbon Brief, CO emissions in China have decreased by $25 \%$ since the end of January ${ }^{22}$. According to NASA satellite data,

\footnotetext{
${ }^{18}$ Temporary guidelines of Ministry of Health of Russia of 1.10.2020 Prevention, Diagnosis and Treatment of New Coronavirus Infection (COVID-19). Available at: https://minzdrav.gov.ru [Accessed 1st April 2021].

${ }^{19}$ Temporary Guidelines of Ministry of Health of Russia of 08.02.2021 Prevention, Diagnosis and Treatment of New Coronavirus Infection (COVID-19), Application of Methods of Amplification of Nucleic Acids, Instructions for Diagnosis of COVID-19 with the Use of Immunochemical Methods, Recommended Treatment Regimens in Outpatient Settings, Recommended Treatment Regimens in Hospital Settings, Recommended Drug Prevention Regimens COVID-19, Instructions for Compliance with Infectious Safety Measures for Field Emergency Medical Teams). Available at: https://minzdrav.gov.ru. Consultant Plus Legal System.

${ }^{20}$ Rules and methods for the disposal of medical waste in the Russian Federation. Reference. Available at: https://ria.ru/20100611/245052738.html [Accessed 01st April 2021].

${ }^{21}$ Ministry of Ecology: against the background of the coronavirus pandemic, the air in the Moscow region has become cleaner. Available at: https://mep.mosreg.ru/sobytiya/novosti-ministerstva/07-04-2020-08-24-25minekologii-na-fone-pandemii-koronavirusa-vozdukh [Accessed 3rd March 2021].

${ }^{22}$ Analysis: Coronavirus Temporarily Reduced China's CO2 Emissions by a Quarter. Available at: https://www.carbonbrief.org/analysis-coronavirus-has-temporarily-reduced-chinas-co2-emissions-by-aquarter [Accessed 3rd March 2021].
} 
nitrogen dioxide (NO) and carbon monoxide (CO) emissions have decreased, and fine particulate air pollution has decreased by $20-30 \%$ from typical levels ${ }^{23}$. Meanwhile, emissions to the ambient air from exhaust emissions decreased due to reduced traffic at the time of the pandemic.

According to the Intergovernmental Panel on Climate Change, global emissions must be reduced by 7.6 per cent every year in the current decade, amounting to 2,800 million tons of $\mathrm{CO}_{2}$ per year; only then there will be a chance of limiting global warming. But within the context of climate change, a slow decline in emission intensity in general does not seem to make such a progress and a significant leap in overall performance will be seen if the full resumption of activities takes place.

Overall, coronavirus has had a negative impact on the environment. According to the American Waste Dive magazine ${ }^{24}$ many enterprises in the US have stopped recycling, and some regions have stopped sorting waste.

Chinese newspaper China Daily ${ }^{25}$ published an article according to which Wuhan produced 200 tons of medical waste every day, up from 50 tons. The amount of incinerated waste has increased since this method of neutralizing waste of the considered hazard class is more often used.

In the Russian Federation, even before the start of pandemic, "about 1 million tons of medical waste was produced... in health care organizations of the city of Moscow in the period from 2007 to 2016; it increased more than by $20 \%$ in terms of epidemiologically significant waste" (Pogodina \& Baranova, 2018:33-37).

The result of the quarantine imposed at the time of the pandemic, according to the United Nations, became "a huge contamination of the planet with plastic"

The study should highlight another issue of practical importance - the licensing of a medical waste management, " $\mathrm{C}$ "-class waste. According to the licensing legislation of the Russian Federation, a lot of activities and types of work or services can be performed only with the license. As established in Par. 4.29 and 4.31 of the Sanitary Regulations, only the export of waste for decontamination or recycling of " $D$ " and " $E$ "class waste is subject to licensing. The licensing activities for " $A$ ", " $B$ " and "C" classes waste is not stipulated by the Sanitary Regulations or the Federal Law "On Licensing of Individual Activities", so it is not an activity subject to compulsory licensing.

Thus, a wide range of economic entities that meet the requirements of the Sanitary Regulations for the collection of medical waste are entitled to activities in the field of medical waste generated by coronavirus infection. The medical waste market is competitive, it is necessary to understand that the large number of persons are entitled

\footnotetext{
${ }^{23}$ Airborne Nitrogen Dioxide Plummets Over China. Available at: https://earthobservatory.nasa.gov/images/ 146362/airborne-nitrogen-dioxide-plummets-over-china [Accessed 1st April 2021].

${ }^{24}$ Municipalities Suspend Recycling due to Coronavirus Impact on Prison Labor, Broader Safety Concerns. Available at: https://www.wastedive.com/news/recycling-mrfs-prison-labor-suspensions-coronavirus-covid19/574301/ [Accessed 3rd March 2021].

${ }^{25}$ Medical waste disposal capacity rises. Available at: https://www.chinadaily.com.cn/a/202003/11/ WS5e681df5a31012821727df81.html [Accessed 3rd March 2021].

${ }^{26}$ Piles of disposable masks, gloves and packaging materials - how the COVID-19 pandemic has turned to the environment. Available at: https://news.un.org/ru/story/2020/07/1382841 [Accessed 3rd March 2021].
} 
to engage in this activity. Meanwhile, in accordance with the explanations given in the Letter of the Federal Service for Environmental Management Supervision ${ }^{27}$ (hereinafter - Rosprirodnadzor), since medical waste of classes " $\mathrm{B}$ " and " $\mathrm{C}$ " is subject to disinfection, after which it can be classified as waste formed in the production process for decontamination of medical and biological waste and regulated by the Federal Law On Production and Consumption Waste ${ }^{28}$.

By virtue of provisions of Art. 24.7 Par. 1 Law No. 89 provides the right of regional operators to enter into service contracts with the owners of any type of waste. The regional operator is thus entitled to deal with multiple waste types. There are no requirements for transportation (or separation) of wastes of different hazard classes and there is a clear risk of abuse when medical Class " $\mathrm{C}$ " waste and covid-waste are transported together with solid household and garbage even after recovery. Therefore, they must not be disposed this way, which could eliminate the possibility of exposure and re-contamination.

However, considering the spread of a new type of infection COVID-19 and the fact that this virus is not fully studied and there is are no guarantees of its destruction with the applied methods of disinfection of class "C" waste, it is better to assign this medical waste to the particularly hazardous I-IV-waste category. Such activities as collection, transportation, treatment, disposal, neutralization, and placement are licensing-compulsory in accordance with the Federal Law On Licensing of Individual Activities $^{29}$. Organizations engaged in collecting, transporting and disposing of data on waste should submit additional requirements. This action would be better carried out at least until the nature of the new virus is fully understood and its viability is evaluated under conditions of applied disinfection of class "C" waste. Licensing of this activity, however, could reduce the next (expected virus mutation) outbreak.

There are legislative initiatives requiring licensing of enterprises who will engage in activities with such waste ${ }^{30}$ (it is currently unlicensed with the support from Federal Service for Supervision of Consumer Rights Protection and Human Welfare, hereinafter - Rospotrebnadzor $)^{31}$. A proposal for additional requirements for regional operators (to deal with export and accumulation contracts, tariffs and export regulations) has been partially implemented. The simplified electronic licensing has been provided for.

Currently there are only two enterprises in Russia that are capable of processing epidemiologically dangerous medical waste; they are technologically intensive and environmentally friendly. Center of 100 Rostov-on-Don company has received

27 Letter of Rosprirodnadzor (the Federal Service for Supervision of Natural Resources Management) N0. AA10-04-32/26588 dated 04.12.2017 On clarifications. Consultant Plus Legal System.

28 Federal Law No. 89 of June 24, 1998 On Production and Consumption Waste. Consultant Plus Legal System.

${ }^{29}$ Federal Law No. 99 of 04.05.2011 On Licensing of Individual Activities. Consultant Plus Legal System.

${ }^{30}$ Official website of the government of the Moscow region. Available at: https://mosreg.ru/sobytiya/ novosti/organy/gubernator/andrei-vorobev-vystupil-s-ezhegodnym-obrasheniem-k-zhitelyam-moskovskoioblasti [Accessed 3rd March 2021].

31 Do I need a license to collect and remove medical waste: Rospotrebnadzor comments. Available at: https://medservise24.ru/blog/zakonadatelstvo-i-medotkhody/nuzhna-li-litsenziya-na-sbor-i-vyvozmeditsinskikh-otkhodov-kommentarii-rospotrebnadzora/ [Accessed 12th April 2021]. 
permission for the disposal of medical class " $\mathrm{C}$ " waste in Rostov region ${ }^{32}$. At the same time, the priority area of its activity is the disposal of waste specifically related to coronavirus epidemiologically hazardous waste (single-use suits, masks, napkins, tools used in contact with infected persons). The covid-waste will be removed from the premises of the institutions for subsequent recycling at the plant only after mandatory chemical disinfection with modern solutions. Last year this specialized centre processed 530 tons of medical waste ${ }^{33}$. At the same time, it may be necessary to legislate for higher requirements for the organizations dealing with medical waste management of the "C" class. But in practice we witness derogation rather than tightening of requirements.

The second enterprise that recycles the covid-waste is "PT-Invest"; it is currently constructing two new plants on the territory of waste processing complexes using pyrolysis or pyrolysis incineration technologies ${ }^{34}$. Meanwhile, the waste is decomposed into molecules (to gases) when burning, and the received gas is burned for the second time to generate energy. The planned recycle amount is $45-50$ thousand tons of medical waste per year with generating electricity effect of $3-5 \mathrm{MW}^{35}$. However, environmental protection is clearly at stake. And within the ongoing reform of solid household waste management, it has clearly been extended to include medical waste.

In early April 2020, the Prime Minister was requested to establish a centralized State information system for accounting, monitoring the collection and disposal of medical and biological waste. This proposal would make it possible to record, monitor and supervise handling of bulk waste (Vlasenko \& Shirobokov, 2021:601-620). However, there is no legal requirement to collect covid-waste separately from other medical class "C" waste, which will not allow to get correct information from such accounting system.

"One hundred thousand tons of waste are formed from more than four thousand medical institutions in Moscow every year and considering export from Moscow it increases up to 300 thousand tons per year"36.

Another initiative related to covid-waste was to keep records of the places where such waste was stored or disposed of during the epidemic, with the introduction of territorial schemes and entrusting implementation to the Russian Environmental Operator of Veterinary Services ${ }^{37}$. But such an initiative is unlikely to be realized due to some separation of the two services and specificity of the profile of veterinary

\footnotetext{
${ }^{32}$ The plant near Rostov received a permit for the disposal of waste associated with COVID-19. Available at: https://don24.ru/rubric/ekonomika/zavod-pod-rostovom-poluchil-razreshenie-na-utilizaciyu-othodovsvyazannyh-s-covid-19.html [Accessed 3rd March 2021].

${ }^{33}$ The plant near Rostov received a permit for the disposal of waste associated with COVID-19. Available at: https://don24.ru/rubric/ekonomika/zavod-pod-rostovom-poluchil-razreshenie-na-utilizaciyu-othodovsvyazannyh-s-covid-19.html [Accessed 3rd March 2021].

${ }^{34}$ The head of RT-Invest - RBC: "The garbage business is absolutely not rich". Available at: https://www.rbc.ru/business/10/02/2020/5e3099c29a7947f06ebb191b [Accessed 3rd April 2021].

${ }^{35}$ The head of RT-Invest - RBC: "The garbage business is absolutely not rich". Available at: https://www.rbc.ru/business/10/02/2020/5e3099c29a7947f06ebb191b [Accessed 3rd April 2021].

${ }^{36}$ Vorobiev proposed to create a system for the removal of medical waste during an epidemic. Available at: https://www.rbc.ru/business/14/04/2020/5e949a2d9a7947cbfef64bd8 [Accessed 3rd March 2021].

37 Vorobiev proposed to create a system for the removal of medical waste during an epidemic. Available at: https://www.rbc.ru/business/14/04/2020/5e949a2d9a7947cbfef64bd8 [Accessed 3rd March 2021].
} 
services. Similarly, another proposal to create a regional operator, specializing only in collecting of medical and biological waste is difficult to implement in practice ${ }^{38}$. It will require separation of medical waste, which is difficult in practice; besides collection of this type of waste in the non-medical sector may be out of control.

These concerns are not exhaustive, as it will also be necessary to amend existing waste management legislation (Federal Law on Production Wastes and Consumption). Such changes will entail the issue of the need to introduce tariffs and regulations on accumulating and export of the type of waste in question, as well as changes to the investment infrastructure and introduction of Public-Private Partnership in this area before issuing licenses for handling such waste.

If there would be an operator that deals only with medical and specifically on covid-waste, it is possible that the price of its services will increase significantly due to the peculiarities of financing such activity as medical. Since financing of a regional operator will come from the budgets of the Russian Federation and local governments, this will also entail a financial interest in involving specific individuals and, likely, corruption in tendering and contracting.

Meanwhile, the initiative to introduce additional disinfection of medical class "C" waste and sewage in each medical organization with special equipment by trained personnel for onward transportation and recycling at the plant seems quite successful. It could minimize the risks to the environment and spread of the virus while transporting the waste (in the event that the pre-disinfection rules are violated, or the integrity of wastes packaging is compromised). In addition, if each medical organization has such waste disposal equipment, there is no need to store the waste, which, after disinfection, falls into category "A". The implementation of these requirements in the framework of planned inspections is to be laid on Rosobodnadzor if there is no moratorium ${ }^{39}$. A surprise inspection is possible in the case of mass disease within a single enterprise; also, sanctions may be imposed on the medical enterprise for violations. However, complying with the requirements of Sanitary Rules and Regulations 2.1.7.2790-10 may prevent such outbreaks.

\section{Non-medical covid-waste}

All of the above is relevant to the management of medical waste in medical institutions. However, in the context of the pandemic in 2020 other waste is also important; many citizens diagnose COVID-19 in non-state medical enterprises and laboratories, are treated in non-budgetary medical institutions, private hospitals, and receive treatment from COVID-19 at home. There are also latent patients who are unaware of a hidden disease and have not visited state medical institutions. They are

\footnotetext{
${ }^{38}$ Vorobiev proposed to create a system for the removal of medical waste during an epidemic. Available at: https://www.rbc.ru/business/14/04/2020/5e949a2d9a7947cbfef64bd8 [Accessed 3rd March 2021].

39 Decree of the Government of the Russian Federation No. 438 of 03.04.2020 On the Specifics of the Implementation in 2020 of State Control (Supervision), Municipal Control and on Amendments to Paragraph 7 of the Rules for Preparation by State Control (Supervision) Bodies and Municipal Control Bodies of Annual Plans for Scheduled Inspections of Legal Entities and Individual Entrepreneurs. Consultant Plus Legal System.
} 
not included in the statistics of patients with COVID-19. To reduce the risk of infection, people are advised to wear masks and gloves ${ }^{40}$.

In addition to residential buildings, covid-waste also occurs in public places. For example, educational institutions have containers with the inscription "for used masks and gloves". But how are these wastes further disposed of? There is no obligation to take them to medical institutions for the disposal. Rospotrebnadrzor has repeatedly explained that medical masks and gloves must be packed in a separate package and tightly closed, and only then discarded with household garbage ${ }^{41}$, provided that the package will not be damaged. However, there is clear understanding that not all waste is packaged in this way. Another question is whether this waste is properly disposed of.

Public service announcements strongly encourage you to change your mask more often. Disposed masks, gloves, etc. were in contact with the infected persons, so this waste is essentially covid-waste. If they are discarded in a garbage bin, they will be transported in a solid household waste and garbage container and then by conventional vehicles are removed to incinerators or landfills of solid household waste and garbage.

So, the materials that were in contact with the covid-patients are the covid-waste outside the medical enterprises. It is not the hospital waste that is of concern, but household refuse, which actually ends up as covid-waste from solid household waste. This can lead to contamination of other people (janitors, garbage collectors, workers at landfills, etc.). At the same time, being covid-waste, it is not classified as medical class " $\mathrm{C}$ " waste but is of the same danger as medical class " $\mathrm{C}$ " waste that is improperly disposed of.

At present the treatment of household waste (inherently infected but legally unrelated) is not regulated by law. Specific legislation is needed to regulate the collection, storage and disposal of COVID-19 medical waste at home. A special collection and disposal of such waste separate from ordinary household waste has to be provided. For example, covid-waste used by infected persons at home has to be collected in special containers. This waste has to be transported by specialized transport to the disposal and provide free access to telephones of organizations involved in that type of transporting and disposal, so that anyone can report about medical waste. People have to be informed about the rules for collection and disposal of medical waste from infected patients treated at home.

Such waste is not medical, although it is covid-waste. However, equating with medical waste would mean significant legal consequences in general. Proposals to extend the concept of medical waste by including other types generated outside such institutions have been voiced by scientists on several occasions (Borodina, 2014:92 - 95). In examining these legal implications, the following conclusions have been reached: in the event that non-medical covid-waste (not from medical facilities and enterprises) should be regulated further, rules governing collection, storage and

\footnotetext{
${ }^{40}$ Doctor: Wearing gloves and masks reduces the risk of mucosal infection. Available at: https://rg.ru/2020/05/14/reg-cfo/vrach-noshenie-perchatok-i-masok-snizhaet-risk-zarazheniia-cherezslizistye.html [Accessed 3rd April 2021].

${ }^{41}$ Information of Rospotrebnadzor of 10.02.2021 On the Disposal of Masks and Gloves at Home. Available at: https://www.rospotrebnadzor.ru [Accessed 3rd March 2021].
} 
disposal of medical waste for COVID-19 treated at home should be adopted. In the event that household covid-waste is assimilated to medical class " $\mathrm{C}$ " waste, it is necessary to provide for separate collection of such waste, including separate from household solid waste and garbage, presumably in special containers distributed to infected persons at home (or to provide free access to such containers). Transportation of covid-waste should be organized to decontamination at the facilities to be installed in all medical establishments; actually, we speak about organized recycling centers. At the same time, telephones of such organizations must be available. There is also a need to inform population about the rules for collecting and disposing of medical waste from infected patients treated at home. Responsible management of medical waste in the context of the COVID-19 pandemic can help to eliminate new sources of infection and prevent the spread of infection, thus preventing healthy people from contaminating objects.

Legal regulation of issues related to managing medical waste, as well as optimizing the processes of disposal of such waste, is of great importance. We need to optimize the disposal of such waste without excessive transportation and recycling; the first step was taken when medical institutions were recommended to introduce decontamination plants for subsequent equating and assimilation of covid-waste to "A"- class waste.

The issue of establishing administrative liability of natural persons as opposed to legal persons (Gromova, 2014:1031-1038) for violation of regulations governing handling of such wastes is being disputed. Liability for such acts (omissions) is least probable because the covid-waste collection duties is almost impossible to control (although there is certain experience in imposing penalties - fines for not wearing face masks by individuals ${ }^{42}$ ). The right option in our opinion is a massive social advertising and moral responsibility for mismanagement of such waste.

At the same time the issue of non-medical covid-waste has been considered by Rospotrebnadzor; in 2020 it recommended temporal suspension of waste sorting in order to avoid re-infecting ${ }^{43}$. The number of people infected with COVID-19 rises daily; it can be concluded that the amount of medical waste associated with treatment of such patients has increased along with the amount of waste generated outside medical institutions.

The annual worldwide event Let's Clear the Planet of Rubbish has become more relevant than ever, because according to Environmental Science \& Technology Journal, every month 129 billion masks and 65 billion gloves are thrown out with solid household waste and rubbish ${ }^{44}$. The figures reflect both environmental issues and potential for re-infection from covid-waste.

\footnotetext{
${ }^{42}$ Non-contact disposal: how to recycle "covid" waste. Available at: https://rostec.ru/news/beskontaktnayautilizatsiya-kak-pererabotayut-kovidnyy-musor/ [Accessed 13rd April 2021].

${ }^{43}$ Rospotrebnadzor recommended to suspend separate waste collection. Available at: https://www.rbc.ru/ society/08/05/2020/5eb51bab9a79477f314a8a4a [Accessed 6th April 2021].

${ }^{44}$ Non-contact disposal: how to recycle "covid" waste. Available at: https://rostec.ru/news/beskontaktnayautilizatsiya-kak-pererabotayut-kovidnyy-musor/ [Accessed 13rd April 2021].
} 


\section{Conclusion}

The research studied the issues of attributing medical waste to the sphere of ownership and specifics of legal regulation of contracts dealing with this type of waste. The work has shown that medical waste being highly hazardous is regulated within the framework of business service. Detailed analysis of medical waste management has been carried out from different angles: legal, practical and organizational.

This topic has been in the focus as a result of the pandemic of 2020 and entailed significant changes in the legal regulation of medical waste. Realization that recontamination through medical covid-waste is possible resulted in installing disinfectants in medical and pharmacological organizations. Division of medical waste into classes predetermined assignment of medical covid-waste to the class with stronger responsibility. New approach to covid-waste and options for its recycling, obligatory special facilities for disinfection of medical class "C" waste (including covid-waste) and its subsequent assimilation to " $\mathrm{A}$ "-class after appropriate decontamination in medical institutions - were the steps taken by the state in their fight with the pandemic.

Though the question concerning the nature of covid-waste and its classification has been raised, it has not got its full answer so far; so, in practice, some types of covidwaste are not recognized as medical. As a result, legislation does not require their appropriate processing such as disinfection. Being mixed with solid household waste it increases the likelihood of re-infection.

The study suggests equating personal protective tools that are not medical waste with medical waste (taking into account the specific nature of collecting and storage) in the context of a pandemic with the aim to reduce the amount of covid-waste in solid household refuse in accordance with the provisions of Art. 49 of the Federal Law On the Fundamentals of Health Protection of Citizens in the Russian Federation.

The work asserts that there is no regulation of collecting, stockpiling, transporting and disposing of covid-waste generated outside medical institution since it is not possible to regulate it as a moral and/or ethical matter. Despite the small lifetime of the virus on surfaces it may be the source of infecting people; this also refers to the issue of coronavirus resurgence, especially under conditions of mutation.

Another problem that was alerted is the fact that one does not need a transport license to remove solid household waste; legislation does not require such a license in spite of the presence in household waste non-medical covid-waste. This is the question that still seeks its solution. The work raises the issue of separating accumulation and disposal of non-medical covid-waste in legal regulation as well as the ways to implement it into practice. Concerning the environmental pollution in the context of the pandemic, the author is of the opinion that medical and non-medical covid-wastes have added to the amount of plastic that pollutes the environment. All the above problems are tied up into challenges that humanity faces as a result of coronavirus infection.

\section{References / Список литературы}

Borodina, I.M. (2014) Medical waste as an object of civil rights. Bulletin of the Volgograd State University. Series 5. Jurisprudence. 2 (23), 92-95. (in Russian). 
Бородина И.М. Медицинские отходы как объект гражданских прав // Вестник Волгоградского государственного университета. Серия 5. Юриспруденция. 2014. № 2 (23). C. $92-95$.

Chartier, Y., Emmanuel, J. \& Pieper, U. (eds.) et al. (2014) Safe management of wastes from healthcare activities. World Health Organization. Available at: https://apps.who.int/iris/bitstream/ handle/10665/85349/9789241548564_eng.pdf?sequence=1 [Accessed 13rd April 2021].

Cherevchina, I.M. (2012) Civil liability in the field of medical waste management. Science and education: economy and economics; entrepreneurship; law and administration. 7 (26), 23-28. (in Russian).

Черевчина И.М. Гражданско-правовая ответственность в области обращения с медицинскими отходами // Наука и образование: хозяйство и экономика; предпринимательство; право и управление. 2012. № 7 (26). С. 23-28.

Gromova, G.A. (2014) Some problems of legal regulation of medical waste management and bringing to administrative responsibility for violations in medical waste management. Administrative and municipal law. (10), 1031-1038. (in Russian).

Громова Г.А. Некоторые проблемы правового регулирования обращения с медицинскими отходами и привлечения к административной ответственности за нарушения при обращении с медицинскими отходами // Административное и муниципальное право. 2014. № 10. C. $1031-1038$.

Mironenko, O.V. (2004) Ecological and hygienic substantiation of the hospital waste management system. Diss. ... Doc. Med. of sciences. Saint Petersburg. (in Russian).

Мироненко О.В. Эколого-гигиеническое обоснование системы обращения с больничными отходами: дисс. ... д-ра мед. наук. СПб., 2004. 431 с.

Mokrousov, I.V. (2006) Hygienic assessment of the nosocomial environment to justify preventive measures with disinfectants. Diss. ... Cand. Med. of sciences. Saint Petersburg. (in Russian).

Мокроусов И.В. Гигиеническая оценка внутрибольничной среды для обоснования профилактических мероприятий средствами дезинфекции: дисс. ... канд. мед. наук. СПб., 2006. 177 с.

Orlov, A.Yu. (2010) Substantiation of the sanitary and chemical hazard of medical waste. Diss. ... Cand. Med. of sciences. Moscow. (in Russian).

Орлов А.Ю. Обоснование санитарно-химической опасности медицинских отходов: дисс. ... канд. мед. наук. М., 2010. 170 с.

Perelygin, V.V., Sklyarova, N.A., Paramonov, S.G. \& Pyatizbyantsev T.A. (2019) Approaches to a comprehensive solution to the problem of medical waste management. Pharmacy Formulas. 1 (1), 78-83. Doi 10.17816/phf18618. (in Russian).

Перельгин В.В., Склярова Н.А., Парамонов С.Г., Пятиизбянцев Т.А. Подходы к комплексному решению проблемы обращения с медицинскими отходами // Формулы Фармации. 2019. Т. 1. № 1. С. 78-83. Doi 10.17816/phf18618.

Pogodina, I.V. \& Baranova, A.F. (2018) On the issue of medical waste management. Medical law. (4), 33-37. (in Russian).

Погодина И.В., Баранова А.Ф. К вопросу об управлении медицинскими отходами // Медицинское право. 2018. № 4. С. 33-37.

Polyaninov, L.Ya. \& Cherevchina, I.M. (2011) Sources of legal regulation of the handling of hazardous medical waste. Gaps in Russian legislation. (5), 120-123. (in Russian).

Полянинов Л.Я., Черевчина И.М. Источники правового регулирования при обращении с опасными медицинскими отходами // Пробелы в российском законодательстве. 2011. № 5. C. $120-123$.

Ponomarev, M.V. (2019) Legal problems of application of administrative responsibility for offenses in the field of medical waste management. In: Constitutional and legal foundations of responsibility in the field of ecology. Collection of materials of International scientific conferences. pp. 352-358. (in Russian). 
Пономарев М.В. Правовые проблемы применения административной ответственности за правонарушения в области обращения с медицинскими отходами // Конституционноправовые основы ответственности в сфере экологии: сборник материалов Международных научных конференций. 2019. С. 352-358.

Ponomarev, M.V. \& Tsomartova, F.V. (2019) Legal regime of medical waste. Journal of Russian Law. (9), 145-158. (in Russian).

Пономарев М.В., Цомартова Ф.В. Правовой режим отходов медицинской деятельности // Журнал российского права. 2019. № 9. С. 145-158.

Vlasenko, V.N. \& Shirobokov, A.S. (2021) Digitalization of state environmental management: Legal aspects. RUDN Journal of Law. 25(2), 601-619. Doi: 10.22363/2313-2337-2021-252-601-619

Zudinova, Ye.A. (2017) Epidemiological and organizational aspects of functioning of medical waste management system in the city of Moscow. Diss. ... Cand. Med. of sciences. Moscow. (in Russian).

Зудинова E.A. Эпидемиологические и организационные аспекты функционирования системы обращения с медицинскими отходами в городе Москве: дисс. ... канд. мед. наук. М., 2017. 168 c.

\section{About the author:}

Алексеева Надежда Анатольевна - кандидат юридических наук, заместитель заведующего кафедрой земельного и экологического права, Российский государственный университет правосудия; Российская Федерация, 117418, г. Москва, ул. Новочеремушкинская, д. 69

ORCID ID: 0000-0003-1514-8465

e-mail: knadege@yandex.ru

\section{Об авторе:}

Nadezhda A. Alekseeva - Candidate of Legal Sciences, Deputy Head of the Department of Land and Environmental Law, Russian State University of Justice; 69 Novocheremushkinskaya str., Moscow, 117418, Russian Federation

ORCID ID: 0000-0003-1514-8465

e-mail:knadege@yandex.ru 